\title{
The Rule of Law at the Cape of Good Hope in the Eighteenth Century
}

by

\author{
Robert Ross
}

According to Rodney Davenport, in the Oxford History of South Africa, 'the rule of law did not exist at the Cape in the Company period'. ${ }^{1}$ This statement seems incredible in view of the immense volume of the surviving legal archives-a volume of the criminal court cases for a single year can easily be over 1000 pages of manuscript ${ }^{2}$-and the large number of placcaaten issued by the government of the Cape of Good Hope in the eighteenth century. ${ }^{3}$ This, so it would seem, is evidence of a society in which the Roman-Dutch law of the Republic of the Netherlands, as amended first to suit the requirements of an castern trading empire and then of the port and colony of the Cape, was used to settle disputes and to maintain public order and the rights of property. South Africa was clearly ruled by a code of law-as indeed is probably every society in the world, in some sense or other-and moreover by one which was based on a system to which more concentrated legal thought had been given, at a higher theoretical level, than any other in the seventeenth and eighteenth centuries. To be sure, there were no jurists of any standing whatsoever at the Cape at the time. Most of the members of the Court of Justice had no legal training at all. ${ }^{1}$ Nevertheless, the codifications and textbooks which they used were among the finest products of the greatest period of Dutch intellectual history. It is doubtful if the "modernity" of the legal system of any other country could be compared with that of the Netherlands in the eighteenth century. Certainly that of the Netherlands could be compared with that of any other country.

The bafllement which Davenport's initial sentence presents is, to a certain extent eased by the rest of the paragraph in question, where he implicitly defines 'the rule of law' as one where the law was imposed 'uniformly" and 'fully impartial[ly]', so that the 'severity of the sentences [did not] depend... largely on the legal status of the offender or the person offended against'. That the contrary was the case was clearly admitted by the Dutch authorities. When, after the British capture of the Cape in 1795, the Court of Justice was informed that the barbaric nature of the capital punishment imposed in Company times was henceforth to be mitigated, so that slives would merely be hanged or beheaded, they replied as follows:

With regard to slaves ... the equality of punishment ceases when they commit olfences against Europeans or free persons, particularly their masters; but this distinction is not peculiar to this country; on the contrary it is grounded upon analogy with the criminal law, according to which the distinction of persons is one of the essential points by which the degree of punishment is measured in most civilised nations, and this 
distinction is especially founded upon the Imperial laws or the Roman law, which from its exactness is not only acknowledged as the law when other laws are silent, but is particularly recommended as such in the statutes which have been issued in the Dutch Indies relative to slaves, and are observed heref.

To a modern western liberal, for whom equality, above all before the law, is a cardinal necessity for just government, these words may be anathema. Nevertheless, the general acceptance of liberal views by Europeans came only after the French Revolution. When these words were written, it was at its height, but its effects had only reached South Africa in the form of a conquering English fleet, rather than as an ideology. Before that time, the principles were different. The ruling ethos of European society was not equality but hierarchy, and the task of the courts of law, inter alia, was to maintain this necessary subordination of underlings and superiority of masters. The British, it should be noted, did not object to differential sentencing, but only to the barbarity of breaking slaves alive on a cross. Given the way in which the courts were used by the British ruling class to enforce deference, the new rulers of the Cape could hardly object to the way in which the Dutch had used the law to maintain the necessary distinctions of status between master and slave. ${ }^{7}$

Because the law was used to maintain the social structure of the Cape Colony, even if often in a fairly violent and brutal way, the slave population was not completely without legal rights. Although the effect of the Dutch experience in Indonesia in forming their attitudes to such matters must not be ignored, what position the Cape slaves possessed was duc largely to the conflict between the Company and the burghers, which was always latent and occasionally explicit. ${ }^{8}$ This conflict was based on two oppositions. First, the Company officials considered that the burghers acted as competitors in their (illegal) private trade and were, indeed, always likely to cause trouble with the officials of the V.O.C. in the Netherlands. Conversely, the burghers resented the restrictions which the company monopolies of buying and selling placed on their actions and on the profitability of their farms and business. This conflict became focussed on the law courts, and thus on the legal status of the slaves, just because this was one arena in which the authority of the Company was imposed on the burghers. The presence of two members of the Burgher Council on the Court (except when employees of the Company were on trial) did little to mitigate the control of the officials over the administration of justice. No separation of powers between judiciary, legislature and administration existed at the Cape. All was concentrated in a very few hands.

It is true that the Company itself owned some 600 slaves throughout the eighteenth century, while the high officials of government were themselves in possession of numerous slaves. While they did not allow these slaves to take any liberties, they did not see their own slaves as great a threat to their hegemony as the competition they feared from the burghers. Indeed, there are slight indications that they were somewhat loath to punish their own slaves as harshly as they did those belonging to private citizens. They did not wish to lose their labour force, but could willingly impose such a loss on 
others, in the name of the public good. Thus, as a class, the main body of slave-owners was remarkably powerless. In most European colonies which relied on slave labour, the great planters had, at the least, great influence over the conduct of government in all its actions. At the Cape their sway did not reach the main institutions of legislation and justice. This meant that the position of the slave with regard to his master was stronger than in many other slave colonies. For as long as the Company maintained its hegemony over the Colony, the balance of power gave the slaves (and the Khoi) ${ }^{9}$ a certain bargaining power that they lost, I would argue, with the collapse of the Company at the end of the eighteenth century. ${ }^{10}$

This strengthened legal position can be shown best in the opportunities which slaves had to make complaints against their owners and to give evidence against them. It does not seem that the Court of Justice treated the evidence of a slave as any more or less trustworthy than that of a white man, even including his master. This remarkable competence seems to have been brought to the Cape, like so much else in terms of legal organisation, from Batavia. In the original Statuten van India of 1642, it was laid down that:

Whenever they have been treated mercilessly by their masters or mistresses, slaves are allowed to complain to the judge, provided they have good and cogent reasons, otherwise [they] will be flogged and sent back home. ${ }^{11}$

At the Cape, and very likely further east as wcll, this rule was interpreted widely. Slaves might not only complain of their own treatment but also might report the harsh punishment meted out to their fellow bondsmen. Indeed the largest proportion of cases instigated by slaves against their masters came when it was reported that the master had brought about the death of one of his slaves, generally as a result of overpunishment. ${ }^{12}$ A typical case occurred in 1732, when Jan Crugel, a farmer from the Joostenberg in Stellenbosch district, was accused of flogging his slave Maarten so severely that he died. The only witnesses to the event-at least the only ones who were prepared to talk-were Maarten's fellow slaves. They testified that, some time previously, Maarten had run away, only to be captured two or three days later by a shepherd. Crugel had ordered him to spend the night chained to a waggon and then had him tied in a 'poolse bok' (a form of rack) and flogged with a sjambok, the hippopotamus hide whip that has remained the symbol of white baasskap in South Africa. After this treatment he ran away again, was again caught two days later, was thrown onto the threshing floor of the farm and flogged once more. This time the punishment proved too severe and he died a short time later. However, his fellow slaves did not complain immediately, as it took them a while to pluck up the courage to visit the landdrost (magistrate) of Stellenbosch. As a consequence, by the time the surgeon came to investigate the cause of the death, he could only state that the medical evidence seemed to confirm the testimony of the slaves. Despite this degree of uncertainty, Crugel was convicted and fined 100 Rijksdaalders, while the court ordered that those slaves who had given evidence against him be sold out of his possession, or that of any of his family. ${ }^{13}$

In many ways, this case was a classic example of Cape justice working, 
somewhat belatedly, for the protection of the slave population. The central government reserved the right of punishment, even of slaves, to itself, at least when what was deserved exceeded ordinary domestic chastisement. Indeed, the procedure seems to have been quite regular and the sum paid in fines by a convicted master was constant (and low, a quarter of that demanded of those who broke the liquor laws). Indeed, it was not necessary for the slave to die for the same laws to be brought into operation. For instance, in 1768, Pieter Casper Hammes was fined the normal amount of 100 Rijksdaalders for knocking out his slave, September van Bougis, with an iron hammer. September had been doing bad work in the forge that Hammes ran, and answering him back, annoying him so much that he was driven to smack the hammer he was using into the back of September's head. Rather surprisingly, September survived and, when he came to, complained to the Fiscaal. ${ }^{14}$ In addition to these occasional bursts of temper, which might nevertheless have disastrous consequences for the slaves, really persistent mishandling could be punished more severcly. In 1767, for instance, Jan Hendrick Gerhard was banned from the Cape Colony for life for persistent violence towards his slaves. ${ }^{15}$ This seems to have been an isolated case, which shows the limit beyond which the Court of Justice would not go in disciplining the more unruly members of the white population. Judicially, the death of a slave was always caused by 'mishandling' and excessive punishment - at any rate when caused by a free man-and was never murder. A master might fear financial consequences from laying into his slaves too hard, but certainly never capital ones.

In view of the leniency with which assaults on slaves were generally treated by the Cape Court of Justice, it might be argued that it gave slaves no effective protection against their masters. To a certain extent, this is true. The fear of punishment can never have been a deterrent to the actions of the slaveowners. The major advantage that slaves gained from the law derived from the fact that those slaves who witnessed against their masters (including all those who had been the victims of assiults) had to be sold to another, hopefully more humane, owner, if their charges were not malicious. Clearly, this could be a real advantage, and thus access to the law, which is what the right to testify entailed, was a real privilege. It is instructive to compare (just for once) the Cape with the southern United States of America in this respect. In the U.S., opposition to the possibility of a black giving evidence against whites was so great that, to quote Genovese:

In Louisiana in 1840 the ultimate irony occurred, when a white man who had incited slaves to insurrection had to be acquitted because their confessions could not be used against him. ${ }^{10}$

Even the Spanish law code of the late middle ages, which is renowned as recognizing the personality of the bondsman, only allowed the slave to accuse his master of specific, very serious offences, such as treason or murdering his wife. ${ }^{17}$ This contrasts greatly with the calm assurance of the Cape Fiscanl when he was asked if it was normal for slaves to make complaints against their masters and if they had the competence to do so. Daniel van de Hengel claimed that: 
This had happened many times, and no-one was unaware that slaves are often ill-treated by their masters, in which case they are just as much entitled to complain as are their masters in the opposite case. As that is the position here, he has nothing more to say in the matter. ${ }^{18}$

Two years earlier, in fact, the Fiscaal had argued that if the testimony of slaves and Khoisan was not accepted against 'so-called Christian belicvers, then in the interior of the country away from the Cape the law would not be able to operate'. ${ }^{19}$ Clearly, for the Company to keep control over its unruly, unprofitable and thinly settled colony, it needed all the help it could get, even when that came from slaves.

In general, of course, the control had to be exercised against slaves. The Company officials were concerned to keep control over the colony and so were occasionally forced to ally with individual slaves against owners, but in general the interests of the V.O.C., and thus of the members of the Court of Justice, tended to coincide with those of the slave owners. After all, it was the slave owners who were responsible for producing the goods on which the Company relied to provision its ships---even if the actual labour was mainly slave. In addition, all social, religious and national ties linked the Company officials, who were after all generally slave-holders themselves, to at least the more substantial of the burghers. Moreover, the only real threat to the colony could come from slaves. The burghers might from time to time complain about the commercial policy that deprived them of many business opportunities, and often left them rather poor, but there would never be any serious attempt to overthrow the rule of the V.O.C. Nor, except for frequent disturbances and stabbings outside Cape Town's pubs-which were in any case generally the doing of sailors-- did whites tend to disturb the peace of the colony. To a certain extent, the major trouble that they caused the Court of Justice came from infringements against the various economic regulations that the Company had decided to impose. Of these, the limitations on the sale of alcoholic beverage, above all wine and brandy, were the most notable. With the slaves, of course, it was different. It must be admitted that there was never any suggestion of a slave revolt with sufficient momentum to challenge the bases of white power. Only for a few years in the late 1730s was there even any suggestion of panic, especially after a group of runaways had nearly succeded in their attempt to set fire to Cape Town. ${ }^{20}$ Rather it was at the level of the individual farm and household that the slaves presented a constant danger to their masters.

Almost all the cases relating to slaves and coming before the Court of Justice were construed as crimes against the persons of their masters, of other slaves, or against property. In the commercial mercenary world of a great merchant company, property clearly had to be protected, but attacks on the authority of the slave owner were far more serious than this. They represented a challenge to the very principle of hierarchy by which the society was organised. Although, for the purpose of maintaining their own control-.-and perhaps in accordance with the castern code of behaviour that their predecessors had adapted in Java- - the V.O.C. officials allowed slaves mether more rights than might be expected by a historian whose experience was limited to the New World, the administration of the Cape, as represented by the Court 
of Justice, clearly saw the maintenance of the proper order of society as one of its most important tasks.

The reservation to itself of punishment of slaves did not imply that the government of the Cape was indifferent to their conduct towards their masters, nor that it considered that the masters should have no say in the disciplining of the slave population. It did not require the breach of one of the numerous regulations limiting the actions of the slaves before corporal punishment, often of a savage kind, was inflicted on an unfortunate bondsman. Rather, slaves who had in some way or other given their masters cause to wish them chastised were sent to the 'Caffers' andtflogged. These, men, who were generally convicts themselves, banned from he East Indies to the Cape, doubled as executioner's assistants. In general, they seem to have acted upon the orders of the Fiscaal, or, in the country district, of the landdrosts, ${ }^{21}$ but the Fiscaal seems generally to have agreed to requests that slaves be punished by his officers for what seem relatively minor offences. ${ }^{22}$ In 1763 , for instance, February van Bataria was frequently sent to the Caffers by his master, Christiaan Daniel Persoon, because his daily peddling of cake in the streets of Cape Town did not bring in enough money. ${ }^{23}$ What the practice meant was, first, that the Cape government retained some sort of control over the exercise of violence and, secondly, that it could mitigate the severity of the punishment. In these aims, admittedly, it was not very successful, as the dividing line between what was reasonable domestic correction and what was an abrogation of the monopoly of force belonging to the Company authorities was very hazy indeed. A slave owner might always plead that he had sufficient reason for overstepping the limits, and this might very well be accepted, as when Robert Schot, a Free Black from Bengal, argued successfully that only by chaining his slaves, in itself an illegal act, could he make sure that they did not escape on their way to Cape Town where he was sending them to have the Fiscaal punish them. ${ }^{24}$ Rather, the Company seems above all to have been reserving its right to be the maintainer of the hierarchy by which the Cape was governed.

The varieties of control that the Company attempted to impose are perhaps best seen from the codification of the slave regulations issued in $1754 .{ }^{25} \mathrm{It}$ is therefore worth devoting a certain amount of attention to the twenty-nine provisions of this placaat, even though all it did was to re-issue various previously promulgated ordinances, in no particularly logical order. The rules may be classified into five main divisions. First, there were those which referred simply to the daily life of the slaves and were evidently not attempts to obviate a threat to the bases of Cape society. Some were clearly measures for the better government of Cape Town, such as traffic regulations (to be anachronistic) and the rules for the disposal of rubbish. Others, notably attempts to forbid the public houses of Cape Town to slaves or to outlaw gambling-both futile undertakings - may have stemmed from a desire to keep the slaves rather better under control, to prevent seditious conversation or to remove one of the temptations for theft. Finally there was a group of edicts which referred clearly to the more ritual aspects and their maintenance among the Cape slaves. The prohibition of smoking pipes in the streets might be explained as an attempt to reduce the danger of fire spreading to the low- 
hanging thatched roofs of the town, and it was clearly preferable for a society which prided itself on its Christianity that slaves should not harrass the congregation as it left the church. On the other hand, there could be no clearer example of the hierarchy, not only between whites and slaves but within the white community, than the regulation that laid down that only 'six, eight or at the most ten slaves, according to the rank of the dead slave's master' might follow the cortège and assist at a slave funeral.

Secondly, there was that category of offences which related to the harbouring of slaves by free men other than their master. To a certain extent these had an economic function. Employing another man's slave was, after all, tantamount to stealing a fraction of his labour power from the rightful owner of that commodity. Nevertheless, there was always the suspicion that such concealment was for the much more serious purpose of helping a slave to run away. Aiding a slave to escape was thus to be considered as theft, and punished accordingly, while putting another man's slave to work was merely considered worthy of a fine of 100 Rijksdaalders, although the slave himself was also to be summarily flogged.

Thirdly, there werc those regulations which related more or less explicitly to the prevention of theft by slaves. The problem that the government had to face was that it was clearly very difficult to control pilfering and housebreaking, above all in Cape Town. Therefore they considered that the only efficient way to do this, in addition to normal detective work (in itself very rudimentary) was to outlaw the selling of potentially stolen goods. For this reason it was laid down that no-one was either to let his slaves sell any goods on the street (except foodstuffs, for which the normal retailers were peddling slaves, especially with regard to cakes and vegetables) or to buy from them. Each of these offences would bring a fine of 50 Rijksdaalders. In addition, if anyone bought goods from a slave at a price below the going rate, or in any other way gave rise to the suspicion that they had been stolen, he was to be punished as a receiver of stolen goods.

Fourthly, there were those rules whose essential purpose was to prevent the possibility of revolt, or to prevent slaves from gathering together to plot. Thus, the officers of justice in Cape Town, both Caffers and the burgerwagt, were ordered to break up, by use of canes, any meeting of thrce or more slaves of different masters on the streets of Cape Town. At times, the court went even further than this to stop potentially dangerous gatherings. About midnight one March evening in 1736, at the height of the panic about slave behaviour, the hurgerwagt caught six slaves sitting together in a garden hut on the lower slopes of Table Mountain on the edge of Cape Town. They were playing dice, apparently, and a pot of rice, one of meat curry and a bottle of arak-which had probably been stolen from their respective masters - stood by them. For this offence, they were each sentenced to be flogged and to wear chains for a year. The reasons that were given were that they could steal from the gardens, plot together and establish contact with the runaways on Table Mountain. In addition, they had candles burning, which could have led to a fire. ${ }^{26}$ At times, clearly, the government considered it of paramount importance to keep the slave population atomised, although they cannot be said to have had any degree of success in this end. 
As a similar measure, no slave was ever to be allowed to carry a firearm, even when herding cattle, a hazardous business in a country where wild animals of the more dangerous sorts still existed. Again, in an attempt to prevent nefarious activities of night-time Cape Town, all slaves were forced to carry a lantern if they were about the strects after ten in the evening, unless they should be accompanying their master or his family.

Fifthly, but perhaps most importantly, were those placaaten which ordered the relations between a slave and his master, or between a slave and another European. It is noteworthy that these included the first two articles of Rijk Tulbagh's codification. They said quite simply:

That a male or female slave who insults, libels, scorns, calumnies or in any way falsely accuses his master or mistress shall be flogged and chained, or punished in some other way according to the nature of the case.

But should in these matters a male or female slave offend to such an extent that he comes to strike his master or mistress, with or without a weapon, he shall be punished with death without mercy.

As will be shown below, slaves were frequently executed for striking their masters. Libel could also be severely treated. In 1762, April van Bengal, a fifty-year-old slave of the immensely rich burgher, Marten Melck, was sentenced to stand under the gallows with a rope round his neck, be flogged, branded and then chained to a wheelbarrow for life and sent to prison on Robben Island. His offence, with a fellow countryman, January, who was to be sold out of South Africa after being flogged and branded, was to have spread the rumour, which turned out to be untrue, that Melck had got his step-daughter with child and then beaten her so that she miscarried. ${ }^{27}$

At the same tine, the government ordered that any slave who jostled or otherwise insulted any European "of no matter how mean quality' would be flogged by the oflicers of justice, unless the slave's master had been present, in which case he was obliged to punish his erring slave.

These laws were backed up by a code of punishment which, to the twentiethcentury historian, seems barbaric in the extreme. To a certain extent this derived from the nature of slavery as an institution. Fines were simply not practical, as legally a slave could not possess property. Similarly, imprisonment hit the master financially without greatly altering the position of the slave, who could not sufler from being deprived of a liberty he did not possess. Only the Company gained fiom the availability of extra man-power, but even this was not very uscful as the lime-works on Robben Island were of relatively little importance for the cconony of the colony. Punishment for a slave could therefore only be corporal, or, of course, capital. ${ }^{28}$

The lowest level of punishment was therefore flogging, which was often coupled with putting the unfortunate slave in chains and then sending him back to his master to work chaned tor a number of years. For somewhat more serious offences, slaves were also bronded, and might indeed be put on Robben Island, very often also in chains. However, the system of legal terror by which the authorities tricd to maintain order over the subject population rested primarily on capital punishment. $A$ ll offences against the person of a 
slave's master, all murders, whether against free man or slave, and many thefts were punished by death. It might be thought that this did not allow any gradation in treatment, but this was not so. Dutch law allowed criminals to be exccuted in numerous different ways. Depending on the severity of the offence, the condemned man died more or less slowly and painfully, and at the Cape these distinctions were ordered in an unwritten but regular patteru. Certain methods of death were reserved for those found guilty of particular crimes. Thus, arsonists were burnt and those convicted of homosexuality or bestiality were drowned, generally tied to their co-respondent. But, for the rest, there was a regular progression of increasing torture which accompanied death. For instance, in the 1760 s the more serious varieties of theft, in particular those where the culprit seems to have been organising a gang, the murder of one slave by another, where no other offence seems to have been committed, raising a hand against a master, and minor participation in what was seen as the plotting of a revolt, were all punished by hanging. Murdering fellow slaves, when this offence was aggravated by other crimes, such as rape or theft, was generally punished by breaking on a cross. Sometimes, the sufferer was put out of his misery by a coup de grace, but frequently he or she was left to die of the pain of hanging from broken limbs. For particularly serious offences, such as mercenary murder, leading the plot for murdering a white man, even this was not enough. Red-hot tongs would be used to pull out eight pieces of flesh before the unfortunate man was broken. Earlicr in the century, the murder of a master by his own slave was punished by sitting the culprit on an iron spike which penetrated up from his anus into his body. Depending on the weather, he took up to two days to die. ${ }^{99}$

As the purpose of this barbarity was not only justice but also deterrent, all these punishments were carried out in public, generally at a regular spot, although those who looted wrecked ships were hanged summarily on the beach. Morcover, so that everyone would have a constant reminder of the consequences of their actions, the corpse of the executed would be left, as the formula had it, 'until the birds and wind destroy it'. Thus the execution place, on the edge of Cape Town, approximately where the central railway station now stands, would generally be adorned with rotting bodies.

As a back-up to the vicious system of punishments, torture was used to extract confessions. This was thought necessary because the Roman-Dutch law insisted that anyone who was to be executed should first admit his or her guilt. This treatment was not reserved for slaves, as it might also be imposed on free men, especially sailors. In fact, relatively few suspects were actually sent to the torture chamber, and once there the sight of the instruments was frequently enough to produce the required statement. Nevertheless, the degree to which the whole system was based on the knowledge among the population that torture would be used to extract confessions can be seen from the adjustment in the rules of court procedure that the British were forced to introduce after they conquered the Cape in 1795. Because they considered torture to be inhuman, they abolished its use, but soon found that about half the murderers were not being executed, since they realised that this could not be done without a confession, and therefore that they only had to remain resolute under questioning for the court to be forced merely to sentence them to 
prison. Since this did not seem to the British authorities to meet the requirements of justice, they had to alter the conditions for conviction and execution, so that it was no longer necessary for the culprit to confess. The normal rules of judicial proof had to be considered sufficient. ${ }^{30}$

Clearly, the efficiency of the judicial terror with which the government attempted to control the colony and to maintain the social order depended on the quality of its police and detective work. This was notably lacking. In Cape Town, the Caffers and the burgerwagt, a sort of police militia, ${ }^{31}$ patrolled the streets, but their chance of catching criminals in the act must have been slight. Where crimes were committed within a household, there must have been a reasonable chance of identifying the guilty party, but more organised theft can only have been detected by the tracing of stolen goods. This seems to have been a fairly rare occurrence, especially as the Chinese community acted as the normal receivers and was particularly difficult to penetrate. ${ }^{32}$ In addition, sailors on the numerous ships were always available to take goods out of the country. However, in the absence of statistical data on the number of crimes committed, it is impossible to give any indication of just how unsuccessful the authorities were.

In the countryside the problem was rather different. Although some of the crimes were the work of slaves who remained with their masters, ${ }^{33}$ the most serious problem came from slaves who ran away. To counteract these, the burghers had to rely on their own strength, as Company forces rarely penetrated across the Cape flats. Thus the commando system, which was a militia force also used against the Khoisan, was employed, above all against large groups. It was not particularly successful. At the end of the century, Lichtenstein wrote that, in the mountains between modern Wolseley and Ceres:

A thousand places of concealment offer the wished for asylums to slaves deserting [the farmers'] service and bands of these robbers not infrequently take advantage of the favourable nature of the spot to harbour in it for a long time together, living on the plunder of the neighbouring flocks and herds, gardens and fields. From time immemorial, this mountain has never been free from marauders, notwithstanding that parties have frequently been sent against them, and numbers have been brought to justice. Some half-instructed travellers have confounded these people with the Bosjesmans; but they have no relation whatever with them. They are much less addicted to murder; but are not so easily taken, on account of the firearms which they have for defending themselves. ${ }^{34}$

Clearly, then, the law could not be imposed on all criminals-as the courts defined them-but then no society in the world has ever had a police system of that efficiency. Given the vast distances in the countryside and the nature of the society in the port city of Cape Town, the authorities probably did worse than they would have done in contemporary Europe. Certainly, they had few funds at their disposal, and their net of agents was too widely spread to be very effective. However, no system of government has ever been able to apprehend all those it 'wished to question', let alone know who committed every crime which comes to their attention. There have always been differences 
in the degree to which they could penetrate the various strata of the societies they claimed to rule, while the personal power and social status of the offender have invariably tended to influence the attitudes of sentencing bodies. The legal system of the Cape of Good Hope was not unique in its failings, nor were they particularly extreme. Its task was to maintain the pre-eminence of the V.O.C. within a general system of social stratification. Too many of the inhabitants of the Cape had all too good cause to regret its success in achieving these ends.

Rijksuniversiteit te Leiden

\section{NOTES}

1. In M. Wilson and L. M. Thompson (eds.), Oxford History of South Africa, 2 vols. (Oxford, 1968-1971), 1, 297.

2. These are to be found in the V.O.C. series in the Algemeen Rijksarchief in The Haguc. 3. Published in M. K. Jeffreys (ed.), Kaapse Plakkaarboek, 6 vols. (Cape Town, 1944-
1951).

4. For a description of the working of justice and the Jegal authorities used, see C. G. Visagie, Regspleging en Reg aan die Kaap van 16521011806 (Cape Town, 1969).

5. In Wilson and Thompson, loc. cit.

6. G. McC. Theal (ed.) Records of the Cape Colony, 36 vols. (London, 1897-1905), I,
302-9.

7. See above all Douglas Hay, 'Property, Authority and the Criminal Law', in Hay et al., Albion's Fatal Tree, Crime and Society in Eighteenth-century England (London, 1975).

8. The two major episodes in this fight were the attack on the governorship of Willem Adriaan van der Stel, which came to a head in 1706, and the Cape Patriot movement of the 1780s. For the former, the classic document is L. Fouché (ed.), The Diary of Adam Tas, (London, 1914), while for the latter, see above all C. Beyers, Die Kaapse Patriotte, 1779-1791, (Johannesburg, 1930).

9. See R. Ross, 'The changing legal status of the Khoisan, 1652-1809', African Perspectives (forthcoming).

10. The evidence for this statement, which I have insufficient space to develop here, can be found, i.a. in C. Beyers, Dic Kaapse Patriotte.

11. J. A. van der Chijs (ed.), Nederlandsch-Indisch Plakkaatboek, 16 vols. (Batavia, 18851897), I, 573.

12. Statistical justification for this and other similar statements cannot be given as yet, but the evidence is sufficiently consistent for figures only to confirm the obvious.

13. Case 6, 29 May 1732 , VOC 4120 .

14. Case 22,12 Nov. 1768 , VOC 4255 .

15. Case 10,2 July 1767 , VOC 4251 .

16. E. D. Genovese, Roll, Jordan, Roll, The World the Slaves Made (New York, 1974), 40.

17. F. Tannenbaum, Slave and Citizen, The Negro in the Americas (New York, 1946),

18. Case 11,28 July 1740 , voC 4146 .

19. Case 2, 27 Jan. 1738, VOC 4135 .

. This will be investigated in more detail in a book on slave runaways on which I am now working.

21. For their numbers, see vol. $152 \mathrm{~A}$ of the archive of the Comité van de Zaken van de Oost Indische Handel en Bezittingen, Algemeen Rijksarchief, The Hague.

22. In the nineteenth century, masters could send their slaves to work on the communal tread-mill, a heavy form of punishment. See M. D. Teenstra, De Vruchten Mijner Werkzaamheden (Cape Town, 1943), 195-6. I do not know if this practice was followed

23. Case 11, 14 July 1763 , voC 4237.

24. Case 14, 27 Dec. 1731, vOC 4117 .

25. These are published in the Kaapse Plakkaatboek, III, 1-7. 
26. Case 5, 22 March 1736, voC 4131 .

27. Case 22, 30 Sept. 1762, vOC 4233.

28. The information presented in the subsequent paragraphs has been inferred from the study of the court proceedings in a systematic way.

29. A. Sparrman, A Voyage to the Cape of Good Hope .. from the Year 1772-1776, edited by V. S. Forbes, translated by $H$. and I. Rudner, 2 vols. (Cape Town, I976-7), II, 257.

30. See A. Sachs, Justice in South Africa (London, 1973), Ch. 2.

31. For its foundation, see Kaapse Plakkaatboek, I, 295.

32. This is shown by numerous cases in the court records.

33. They were generally convicted of petty larceny, of such commodities as sheep, vegetables and wine.

34. H. Lichtenstein, Travels in Southern Africa in the years 1803, 1804, 1805 and 1806, translated by A. Plumptre, 2 vols. (Cape Town, 1929-30), I, 168. 